\title{
A comparative study of appropriateness and mechanisms of hard and soft technologies transfer
}

\begin{abstract}
Technology transfer continues to play a significant role in fostering economic growth, enterprise and human capability development in many emerging and developing economies. In this paper, we examine the appropriateness and mechanism of hard and soft technology transfer in the African cotton industry. Focusing on Uganda, a land-locked African country, we comparatively examined the appropriateness and pro-poor nature of Indian and US made hard and soft ginning technologies transferred into Uganda. Data for our inquiry come from two cotton ginneries in the eastern region of Uganda. We found that a technology transferred into a developing economy can only be appropriate if both the hard and soft component of the technology is transferred into the economy. Our study also reveals that while ginning technologies from India appear to be much more appropriate relative to those from USA, they are not environmentally friendly and affordable for those at the bottom of the pyramid. In addition, the long staple cotton lint the Indian made technologies churn out tends to attract higher prices on the international market. Nevertheless, ginning technologies from the United States tend to have very high rates of production. Implication for theory and policy are presented.
\end{abstract}

Keywords: Cotton ginning, hard and soft technology, appropriate technology, technology transfer, India, Uganda, USA

\section{Introduction}

Innovation and technology researchers have begun to increasingly develop comprehensive models of technology transfer to developing countries (e.g. Majidpour, 2016; Costantini and Liberati, 2014; Archibugi and Pietrobelli, 2003; Bell and Pavitt, 1993). While these studies have extended our understanding on the wider social, historical, and economic context within which technology transfer succeed or fails, the transfer mechanism, and appropriateness of these technologies, which can be decomposed into capital equipment, intermediate goods, and consumer goods and services have not been fully explored (Botchie et al, 2016; Kaplinsky, 2011).

While the concept of technology appropriateness for developing countries has received scholarly attention, a bulk of the seminal works was published before the 1980s. These studies were widely developed in the context of not-for-profit indigenous technologies and their relevance towards poverty reduction (Kaplinsky, 2011). It was only until the 1990s that technologies from foreign sources were recognised to be more appropriate for northern economies and relatively not exactly suitable for developing countries (Kaplinsky, 2011). In recent times, high demand for new 
technologies in low-income markets as observed by Prahalad and Hammond (2002), presents an extraordinary opportunity for multinational organisations in the northern economies to seek their fortunes and bring prosperity to those at the bottom of the pyramid (Dey et al.,2013) Nevertheless, empirical evidence rather suggests that emerging economies, led by China and India appear to be taking advantage of this opportunity than their Northern counterparts (Lema and Lema, 2012; Kaplinsky, 2011). In making sense of this empirical puzzle, researchers have invoked the larger spread effects, leading to smaller gaps in technological know-how between south-south, and the appropriateness of these technologies by virtue of been induced in similar context as the fundamental factors driving the emerging south-south technology transfer trends (Amanor and Chichava, 2016; da Nobrega Cesarino, 2013). By appropriate technology, we refer to any form of hard and soft technology that is accessible, affordable and simple to use, with its embodied knowledge and skills easy to acquire and transferred to users of the technology (Los and Timmer, 2005; Hazeltine and Bull, 2003). In this regard, Kaplinsky (2011, pp.193), argues that "the very large size of China and India, coupled with their growing technological capabilities and the rapid growth of low-incomes, makes it likely that they will become the dominant sources of technological innovations for the poor".

The focus of this paper is on a relatively under-researched dimension of the appropriateness' of technologies transferred into developing countries- a comparative study of the appropriateness and mechanisms of hard and soft technologies transfer in a developing economy. As part of a national foresight exercise aimed at improving national competitiveness, we focus on the Ugandan cotton industry to examine cotton ginning technologies transfer from the USA (representing northern economy) and India (representing emerging economy), to ascertain their appropriateness and mechanism of transfer into Uganda. We develop our contribution at a time when Indian made ginning machines; by virtue of their cheap price have come to dominate the market, even though most Ugandans tend to consider technologies from the northern economies as the most reliable and efficient (Kaplinsky, 2011). Data from the World Integrated Trade Solution (WITS) of the World Bank 
shows that import value of ginning technologies from India ${ }^{1}$ to Uganda increase from US $\$ 9,400.00$ in 2000 to US $\$ 232,000$ (see Figure 1 below). Contrariwise, the value of cotton ginning technologies imports from the USA into Uganda remains significant but has underperformed when compared to India.

\section{Insert Figure 1 about here}

Such investigation is relevant and valuable as technologies transferred into African countries, in particular, are creating conditions for emerging indigenous and local firms to flourish and thrive (Amankwah-Amoah, 2015). Despite this noticeable trend in a shift towards the adoption and utilization of technologies in many developing countries, recent STI reports have concluded that over reliance on inappropriate technologies is one of the main causes of their under development and high levels of poverty, particularly, in many African countries (World Economic Forum, 2013). For example, some of these transferred technologies are not suitable for developing countries environment; hence may lead to the creation of inequalities in job creation, incomes, and consumption patterns (Chataway et al. 2014). Such problems, we follow scholars such as Papaioannou (2014), Chataway et al. (2014) and Kaplinsky (2011), to suggest, can be partly explained by the mechanism of transfer and the inappropriateness of these technologies. Our premise is that the strategic importance of appropriateness lies at the core of hard and soft technology transfer to developing countries (Paunov, 2013), since consumers and firms without the relevant competence and abilities cannot effectively adopt and utilize a given technology to enhance their capabilities and improve their welfare.

The paper is structured as follows. The second section is a brief review of the literature on technology appropriateness and transfer in developing countries. Following this, we provide an

${ }^{1}$ Uganda has for many years had a human capital skills set that is of Asian (predominately South Asian/ Indian) origin, hence the presence of ginning technologies from India in Uganda, we concede also has deep historical roots (Baffes, 2009). 
overview of the ginning technology in the cotton sub-sector in Uganda. Next is our research methodology. The penultimate section is our research findings. We conclude with a discussion of our findings, and its implications for policy and economic development.

\section{Technological appropriateness in developing countries}

The concept of appropriate technology is frequently used to refer to any small-scale technology that is simple enough that people could adapt to meet their socio-economic needs. For Stewart and Ranis (1990; p.4.), it is a "technology which best makes use of a country's resources to achieve its development objectives". In developing countries, appropriate technologies make best use of available resources because they are labour intensive, less skills intensive and less reliant on infrastructure, and operate on small scale basis. Thus, unskilled labour in developing countries are able to use them because they are less skills intensive-thereby leading to the creation of more jobs (Chataway et al. 2014; Kaplinsky, 1990). Technologies that are appropriate for developing countries are less reliant on infrastructure because they often do not require electric infrastructure to operate (Kaplinsky, 1990). From this perspective, Schumacher (1973) advocated for the development of $\$ 100$ technologies that are simple, affordable and less reliant on infrastructure. Schumacher's proposal gave rise to the publication of three major studies by the Organisation for Economic Co-operation and Development (OECD) (1976), The World Bank (1976), and the United States Agency for International Development (USAID) (1976). The three publications made a very strong argument against the reliance on northern capital intensive technologies in developing economies. They argued that developing countries do not have the capacity to generate resources-financial, human and infrastructural-that would mitigate the developmental challenges in key sectors of their economies.

The three documents further argued that capital intensive technologies generally have socially disruptive repercussions and in many cases were introduced in developing economies as a result of distorted factor prices and protection. The technologies tended to produce for either the high income group of the domestic economy and/or for export purposes. They argued further that capital 
intensive technologies are usually not adapted for the supply of labour in developing countries. Hence, the industrial sector generally suffers from under-utilised capacity and excess downtime. This stifles growth of technological capacity and innovation in developing countries. It also leads to very adverse developmental outcomes. Thus, they argued that technology in developing countries must be appropriate.

The traditional appropriate technology movement as espoused by the international organisations in the 1970s and 1980s were overwhelmingly driven by not-for-profit organisations. More recently though, a new school of thought have postulated that the rise of emerging economies such as China and India suggests that this dominant trajectory may be subject to change and that-for-profit appropriate technology may become increasingly prevalent. This is driven not just by the growth in capabilities in these economies but also because the rise of some Asian economies, like China and India, has coincided with a rapid growth in demand by poor consumers. These poor consumers may aspire to branded positional goods, but because of their low incomes will settle for simpler and lower quality products (Kaplinsky, 2011). This form of demand from poor consumers has reignited the appropriate technology concept with China and India serving as the likely sources.

The re-emergence of the appropriate technology concept has come in the wake of advocacy for profit oriented less skills intensive technology for the poor since there is more unskilled labour than skilled labour in developing countries (Papaioannou 2014; Chataway et al. 2014; Fu et al. 2011; Kaplinsky, 2011). This is one of the main reasons why Fu and Gong (2011, pp 1214) argue that firms using "unskilled labour augmenting technology will be more efficient than firms using skilled-labour augmenting technology in low-technology industries" in developing countries. However, Fu et al. (2011) makes an important point that the fact that a technology is labour intensive does not always mean that the technology is efficient and appropriate. This is because there are differences in endowments between countries in developing economies, and demand for skilled labour varies across industries. This makes appropriateness subjective since foreign technology in a developing country hinges on the characteristics of the factor endowments of the country. 
An earlier study by Willoughby (1990) explained further that appropriate technologies can only meet the economic, social, and environmental objectives of a country if the country's factor endowments are suitable for the technology. Therefore, a developing country with highly trained human resource will classify some skills intensive technologies appropriate. Those with less highly trained human resource will consider the same technology inappropriate. He further argues that lack of human capital and the subjective nature of the appropriate technology concept make it difficult for proponents of the appropriate technology concept to consider environmental issues. As a result, most developing countries are unable to collect data on environmental appropriateness of a technology (Willoughby, 1990). Studies such as Kaplinsky (2011) argued that the reason why proponents of appropriate technology do not emphasis on environmental appropriateness of a technology is because developing countries are not fussed about the consequences of environmental issues. This may not be entirely accurate since there are growing concerns about the consequences of greenhouse gases in developing world. We will discuss the environmental appropriateness of two alternative technologies in a later section of this study.

\section{The concept of 'hard' and 'soft' technologies}

Two components of technology emerges from the appropriate technology literature-the hard and soft technology. However for many years, hard technology has dominated the description of technology (Schoffner et al. 2000); and this has resonated across proponents of the appropriate technology concept. Most empirical studies that were conducted to support appropriate technology in developing countries focused on the physical component of the technology (see Stewart, 1982; Bhalla, 1985 and Kaplinsky, 1990). This is largely because of how the concept of technology has been defined over the years. For instance, Clark and Staunton (1989) define technology as machines and equipment that are employed in a production process. Jin (2005) indicates that hard technology exists because of invention which in turn is the result, according to Schoffner et al. (2000), of its physical usefulness to 
society. These tangible physical technologies can be termed "hard technology" (Mokyr, 2003). They are also commonly referred to as artefacts (Mokyr, 2003).

However, Burgess and Gules (1998) argue that the experience, knowledge, and skills associated with a technology are very important for efficient operation of a technology. Thus a technology cannot be useful if it is not accompanied by the requisite knowledge it requires for its operation. For instance, what is done with a ginning machine as a technology depends on the way it is used by the ginning machine operator, how it is incorporated in a wider production process and even the machine repairer in the case of machine breakdown (Mokyr, 2003). These disembodied skills and procedures are termed "soft" technology. Soft technology depends on a combination of experience, skills, knowledge and organisation. In order to ensure efficiency, there is the need for effective coordination between hard and soft technology.

The development of soft technology is a result of the gradual and deliberate approach of acquiring the knowledge embodied with the technology (Dobler et al. 1990 and Lamming, 1993). The acquisition of knowledge, how it is used and passed on in an economy is key to economic growth (Jensen et al. 2007). Specifically, two forms of knowledge have been recognised as important for ensuring economic growth: codified knowledge and tacit knowledge (Polanyi, 1966, Nelson and Winter, 1982, and David and Foray, 2001).

Jin (2005) explains that tacit knowledge requires 'thinking technology' and cannot be properly presented easily in a written form, often being embodied in a technology. It is difficult to communicate tacit knowledge in a formal manner or standardised manner (Jin, 2005 and Bascavusoglu, 2005). Experience is important in mastering tacit knowledge and the transmission of tacit knowledge almost always requires face-to-face interaction. David and Foray (2001) on the other hand argue that writing knowledge down is one way of codifying tacit knowledge. This is one of the surest ways in which knowledge can be passed on to others and be understood by those who can read and understand the language. However, Johnson and Lundvall (2001) argue that in reality codified and tacit knowledge goes 'hand in hand'. This study considers technology from a hard and 
soft perspective. Though we recognise the importance of tacit and codified knowledge in the soft technology literature, our focus is not specific to these aspects of the soft technology literature. Generally, we limit our discussion on soft technology to experience and skills transfer in cotton ginning, specifically, by analysing the appropriateness of these soft technologies in the context of how it is transferred into the country.

\section{Technology transfer}

Transfer of technology to developing countries has been a widely discussed area in international business and development over the past three decades. In particular, the role of multi-national corporations in the process of developing and transferring technology across national borders has generated special interest. Some academic studies define technology transfer in the context of either movement of soft (see Bi et al. 2017; Wahab et al. 2012; and Chun 2006) or hard technologies (Botchie et al. 2016) from their country of manufacture to the final user. Other studies also define technology transfer as the transfer of hard technology-physical artefact-and soft technology-experience, know-how, and knowledge from one entity to another (Souder et al., 1990; Ramannathan, 1994; and Bozeman, 2000).

Studies that define technology transfer in the context of soft technologies argue that the cornerstone of technology transfer is the transmission or movement of knowledge from a technology developer to a final user (Wahab et al. 2012). Chun (2006) added that it relates to the processes through which an organisation or a country transfers scientific or technological achievements to new users. Chun further explained that the design and technical knowledge that accompanies new scientific and technological achievement must demonstrate efficiency in production. Maskus (2004) further indicated that technology transfer does not only focus on the transfer of technological knowledge or information but also the ability for the technology recipient to learn and absorb the technology. 
One of the main ways in which a technology can be absorbed is when the final product of the technology is used (Sahal, 1981). Some studies argue that the technologies that are already embodied in hard technologies are the soft technologies. Therefore, technology transfer must involve the transfer of both the hardware and soft knowledge associated with it (see Sahal, 1981; Kaplinsky 1990; and Botchie 2015). Transferring only the hardware (i.e. machine) without the soft technology will make the transfer process ineffective (Sahal, 1981 and Sahal, 1982). This explanation has been validated by a recent structured survey of the effectiveness of technology transfer in China conducted by Li-Hua (2006), which found that technology transfer in China has become efficient because the transfer process combines both hard and soft technologies. This study follows the school that argues that both hard and soft technologies must be transferred in order to make the transfer process effective. In the next section, we examine the three dominant modes of technology transferinternational trade, foreign direct investment (FDI), technology licensing and cross border movement of personnel (Milner, et al. 2013, Morrissey and Rudaheranwa 2012, Rudaheranwa, 2009, Maskus, 2004, Nicholson, 2002, Smith, 2001, Coe, et al. 1997), from one country to another.

\section{International trade as a mode of technology transfer and appropriateness}

International trade is central to technological change and forms the main vector of technology transfer to developing countries (Coe et al., 1997, and Maskus, 2004). This involves the movement of machinery from its country of origin to the recipient country (Hassan et al, 2015). International trade is one of the fastest means of transferring a technology from its origin to the recipient country. However, the cost of transfer through trade varies according to the location of the recipient country (Faye et al. 2004, Milner et al. 2013, Morrissey and Rudaheranwa, 2012). From this perspective, a landlocked country will incur higher costs in transporting a technology than its maritime neighbour. For example, the cost of transporting a technology to Uganda is higher than that of its neighboursKenya and Tanzania (Rudaheranwa, 2009). This means that the build-up cost involved in importing a technology into Uganda-a landlocked country-may be more expensive than that of its maritime 
neighbours-Kenya and Tanzania. By extension, a given technology is more likely to be less appropriate in a landlocked country compared to a country with maritime borders.

Milner et al. (2013) use data from a range of sources to estimate transport costs for imports to, and exports from, Uganda. They calculated the effective protection of imports and implicit tax on exports due to transport costs and compared it to the effective protection due to trade policy barriers. Their results show that high transport costs - as a result of the country's landlocked nature-are more harmful to Uganda than bad trade policy. They also observe that the landlocked nature of Uganda will make access to goods and services very difficult. Milner et al. (2013) recommend improved infrastructure and institutional support to facilitate trade and reduce the adverse effects of natural barriers. They further indicate that international trade is the most common and easiest approach to technology transfer, but for investment in technologies can help in efficient absorption and utilisation of the technology. Prahalad and Hammond (2002) also buttresses on the importance combining trade and investment to promote technology transfer to the bottom of the pyramid.

\section{Technology transfer through foreign direct investment (FDI)}

FDI is a cross-border investment by a resident entity in one economy with the objective of obtaining a lasting interest in an enterprise resident in another economy ( $\mathrm{Vu}$ et al. 2008 and UNCTAD, 1999). In Uganda for instance, FDI from the China and India, and Europe is among the important conduits for technology transfer for local cotton ginners in Uganda (GoU, 2009). Borensztein et al. (1998) explain that to be successful, FDI as a means of technology transfer generally requires imports of products, adoption of foreign hard technology and acquisition of soft human capital-soft technology. However, Borensztein et al. (1998) identifies acquisition of soft technology in a host economy as the key challenge for successful technology transfer. That is why Mansfield and Romeo (1980) stated that FDI as a means of technology transfer can generally only be successful if there is available capacity such as skilled labour to absorb the transferred technology. This also means that FDI can be a very good conduit for both soft and hard technology transfer in one developing 
country but may fail in another if there is not adequate capacity to absorb the technology (UNCTAD, 2010). For instance, Collier (1999) explained that the Indians were in control of Uganda's super performing cotton ginning industry in the 1960s and early 1970s, but their expulsion led to skills deficit in the ginning sector. Though the Idi Amin government made efforts to invest in ginning technologies, cotton lint production significantly dwindled. This was attributed to the fact that there was no FDI in the sector (Collier, 1999). He argues Uganda should have formulated policies that will attract investor who have expertise to operate the sophisticated cotton ginneries that the Indians left behind.

Aitken and Harrison (1999) also argued in favour of Collier by indicating that the net effect of FDI on domestic plants productivity is very small. They used more than 4,000 Venezuelan plants between 1976 and 1989 to show that there is a robust positive relationship between an increased foreign equity participation and performance of small plants. They also observed a robust positive relationship between FDI and large scale enterprises but this relationship disappears when they take into account plant differences. They also strongly argue that FDI does not led to technological spillover like skills and knowledge transfer to domestic firms. This conclusion by Aitken and Harrison may be specific to Venezuela and perhaps other few economies. Studies like Iamsiraroj and Ulubaşoğlu (2015) used FDI data across 140 countries (from 1970 to 2009) to show that FDI has a global positive effect on technology transfer and general economic growth, but the extent of growth will vary from one country to another. They however, indicated that countries that are opened to trade and financial development stands in a better position to benefit from FDI. Other studies such as Mansfield and Romeo, (1980) and Botchie et al. 2016 have argued that FDI is the cheapest means of technology transfer as the recipient country normally incurs no cost in the acquisition of new technologies.

Studies have shown that FDI as a means of technology transfer is often a sufficient condition for increased productivity and economic growth in a recipient's country (Vu et al. 2008). Zhang (2001) uses data from 11 economies in East Asia and Latin America to show that FDI influences economic 
growth. Vu et al. later on confirmed Zhang's study by using sectoral FDI inflow data on China and Vietnam to analyse sector- specific impact of FDI on growth. Their results show that FDI has a positive effect on economic growth and this is achieved through a direct interaction with labour $(\mathrm{Vu}$ et al. 2008). They further demonstrate that the positive relationship between FDI and economic growth vary across economic sectors, with the industrial sector attaining the highest growth through FDI compared to agriculture and services sectors. Amin Almfrajia and Almsafirc (2014), goes further to argue that FDI can positively improve economic growth in a country/or a sector within an economy if it there are appropriate human capital conditions and a stable macro-economy.

\section{Cross border movement of people}

The transfer of soft technology is an important part of technology transfer. Cross border movement of technical and managerial personnel is one of the most important channels for the transfer of soft technology. This happens when the technology requires the complementary services of engineers and technicians who must be on-site for some period of time to ensure proper installation and efficient operation of the machines. This may lead to the transfer of skills from expatriate workers to local workers in recipient countries. This will also enhance the appropriateness of technologies for indigenous Ugandan employees, since they may be able to uptake technological skills from the expatriate workers. However, this may be more restrictive and less flexible, raising the costs of such transfer and absorption (Maskus, 2004). The immediate recipients of new technologies can gain higher productivity with a lower the cost of production. This is because the firm may be able to host and employ the expert who has crossed borders for their production activities (Maskus, 2004).

Though important for a landlocked country like Uganda, little research has been conducted to investigate the relevance of these modes of technology transfer for the growth of its manufacturing sector. Mutambi et al. (2013) stresses the need for small and medium scale enterprises to develop their internal capacity through efficient adaption and use of products and process technologies imported into the country. Moreover, the technology transfer literature has not sufficiently addressed the issues 
confronting Uganda as a landlocked country. Only Milner et al. (2013), Morrissey and Rudaheranwa (2012), and Rudaheranwa (2009) capture this as an issue. Even these focus mainly on trade policy and the hard technology and less on appropriateness. Furthermore, there are limited empirical studies to show the role of the $\mathrm{AD}$ economies in the transfer of technology to developing countries, and specifically not to Uganda. Available studies mainly consider the transfer of technology from northern economies (see Maskus, 2004, Bozeman 2000 and Stewart, 1982). Technology transfer has invariably been looked at from the perspective of technologies moving from a developed economy to a developing economy.

Considering the existing scholarly gaps, our study seek to examine the appropriateness of hard and soft technology transferred from the northern (USA) and emerging economies (India) into Uganda, focussing on the accessibility and affordability of these soft technologies to the user.

\section{Research Context: Ginning technology in the Ugandan cotton sub-sector}

We develop our contribution in the context of the global cotton industry where the linkages between the industry's structure and the employed ginning technology in a given country impact the overall cummulative output and profitability (Estur and Gergely, 2010; Baffes, 2009). Cotton ginning in its strictest sense is the process of separating cotton lint from the seed so as to place the fibres in an acceptable package for commerce (Baffes, 2009). Thus, a seed cotton produces two main productsthe cotton lint and seed. The cotton seed usually serves as raw material for cotton oil mills for conversion into a number of valuable products. However, the cotton lint remains the most vital raw material on the international market; hence the design and operation of a cotton gin is usually towards the production of desired staple cotton lint (Anthony and Mayfield, 1994; Gordon and Hsieh, 2006).

Uganda, our empirical research focus has 43 ginneries and these ginneries have a combined installed average annual seasonal ginning capacity of one million bales of lint (CDO, 2009). However, only $5 \%$ of the total cotton produced is processed by the two existing local textile factories in Uganda. 
The remaining $95 \%$ of the cotton lint is exported. Export figures as at 2011 shows that the major importing countries are Singapore (55 percent), Switzerland (23 percent) and United Kingdom (17 percent) (Ahmed and Ojangole, 2012). China, Kenya and Tanzania are minor importers of Ugandan cotton (Ahmed and Ojangole, 2012). According to CDO (2009) almost all the ginning technologies operate at only a third of their capacity. This has partly been attributed to lack of appropriate technology to increase production (CDO, 2009). Again, between 2001 and 2010 average ginning outturn (GOT) was $0.35 \%{ }^{2}(\mathrm{CDO}, 2009)$. There are two main types of cotton gins - the roller and saw gins.

\section{Roller ginning technology}

Roller gins are the commonest type of gin in Uganda. There have been many variations and refinements in how the technology work in many countries around the world but its fundamental principle of a harsh pulling of fibers from the seed coat has not changed. There are two main types of roller gins currently used in Uganda. The first type is the double roller gins (DR) which has two leather rollers passing through a stationary knife and rotated in opposite directions.

There are two main types of roller gins currently used in Uganda. The first type is the double roller gins (DR) which is produced in India and has two spirally grooved leather rollers which are pressed against a fixed knife for rotation at about 90-120 rpm (Patil and Padole, 2003). The double roller gin is powered by a 2 horse power electric motor with a diameter of $25 \mathrm{~mm}$ and revolves with a speed of $1440 \mathrm{rpm}$ (Patil and Padole, 2003). It also has a crank shaft pulley of $125 \mathrm{~mm}$ with a speed of $288 \mathrm{rpm}$ (Patil and Padole, 2003). In addition, it has a central assembly known as the beater-which oscillates by means of a crank or eccentric shaft close to a fixed knife. During operation, fibers are gripped between a roller and the knife, and stretched to be separated from seeds (Patil and Padole, 2003). The space through which fibers are stretched is so narrow that it does not permit seeds passing

\footnotetext{
2 Though, current GOT figures are not readily available, it is expected that the trend will remain the same considering the fact that not much has changed in terms of infrastructure and the variety of cotton used.
} 
through with lint. The separated seed drops down through the grid which is oscillating along with beater. The second type is the rotary knife roller gin. The rotary knife roller gins (or rotobar) on the other hand combine a stationary knife with a rotary knife to allow high speed. Turkey, United Kingdom and USA manufacture the rotobar gins but USA has since the year 2000 switched to the production of saw gins.

\section{Saw ginning technology}

Saw gins are mainly produced in the United States of America. They operate by pulling cotton lint from the seed with saw teeth through metallic ribs. Each saw passes between two stationary steel ribs spaced in order to allow the lint to pass through while preventing the cottonseed from doing so. The main parts of a saw gin are saws, ribs and a blast of air for cleaning the lint from the saws. Just as the proponents appropriate technology indicated, the saw gin (which is from the USA) operates on a very large scale and they are faster than roller ginning. However, they produce a relatively shorter staple length. The number of saws per gin ranges from 90 to 200 and this determines the size and the capacity of a single gin stand. The number of installed gin stands and their associated saws determine the capacity of a ginnery (Lumus, 2013). The saw ginnery in Uganda uses an American made 170 saw gin with $150 \mathrm{hp}$ and a $305 \mathrm{~mm}$ diameter saw gins (Lumus, 2013). Historically, it is known to produce clean and good cotton lint. However, this will depend on the operator's skills and experience (Lumus, 2013).

\section{Methodology}

We conducted our study in the Eastern region of Uganda where cotton ginning firms account for more than half of the local economy. Data collection comprised two phases. The first stage started with archival research to unearth the trends in ginning technologies trade between Uganda and its 
main partners-India and the USA. The archival research came from international databases such as World Development Indicators, World Integrated Trade Solutions of the World Bank, official government document reports and other academic publications. We complemented this with Ugandan government reports such as the Uganda 2012 Statistical Abstract (GoU, 2013), projections of demographic trends in Uganda 2007-2017 (GoU, 2010), Uganda National Textiles Policy (GoU, 2009) and the Uganda Industrial Policy (GoU, 2008).

The second phase involved the selection of two ginning firms located in the Gulu and Bulangira districts which served as our empirical research context. We purposively selected these two firms because of their managements' readiness to grant us access and permission to conduct the research in their organisations. There are only two saw ginneries of which both originate from the Northern economies. One is an obsolete British made ginnery located in Kasese-Uganda which is not operated regularly. Hence, we decided not to consider that ginnery. The second saw ginnery is located at Bulangira. All the cotton gins at the Bulangira Ginnery were manufactured in 2009 in the United States of America (USA), and were first operated in 2010 in Uganda, which coincides with the year the Gulu cotton gins started operating. The two ginneries are among the largest in the country. The Bulangira Ginnery employs 121 ginning machine operators (i.e. $80 \%$ of the total employees of the firm). These are junior ranked employees directly involved in the operation of the ginning machines. Senior staff members are 30 in total (i.e. $20 \%$ of the total number of employees)-mainly engineers, managers and firm owners. This firm purchases cotton from 45,000 cotton farmers in Uganda. The Gulu ginnery on average employs 240 workers for cotton ginning and buys cotton from almost 30,000 cotton farmers in the country. We started the sampling process by first obtaining the total list of ginning machine operators from the management in each firm. We then obtained the list of registered employees from management of both organisations and then randomly picked a first respondent on the list from each organisation. We then randomly selected the 3rd registered employee in each firm. In total, we sampled 40 ginning machine operators in the firm that uses the American saw gin. We also sampled 80 ginning machine operators from the firm that use double roller gin. The rational for 
sampling the cotton ginners is mainly because they have a full knowledge of the characteristics of the ginning machines. They also understand the functions and operations of the ginning machine since they are responsible for the day-to-day operations of the ginning machine. Furthermore, we purposively sampled 5 senior staff in each firm. We sample these respondents mainly because we are also interested in eliciting how the ginnery firms are able to secure a transfer of ginning technologies from their respective country of origin to their final destination in Uganda. Table 2 is a summary of the background characteristics of the research participants.

\section{Insert Table 1 about here}

Beyond the respondents within the company, we also purposively sampled 2 key informants in the Ministries of Trade, Industry and Cooperatives in Uganda; and 1 key informant from Uganda Revenue Authority. These are experts in the cotton sector who were willing to assist us to understand the relevance of the cotton sector to the Ugandan economy. We also purposively sampled 2 respondents from the Uganda National Bureau of Standards. We sampled these respondents because we are interested in unpacking the role of standards in technology appropriateness and transfer of technology in Uganda.

The main data for our empirical inquiry were collected through semi-structured interviews with each lasting an hour. The full data analysis followed three steps after all the interviews were audio taped and transcribed. First, we employed the constant comparative approach (CCA) (Glaser and Strauss, 2012), to compare our new collected data with previous data that was collected for earlier studies on a closely related subject (Ragin, 2014; Hewitt-Taylor, 2001). Second, we used an open coding approach to identify common themes related to technological appropriateness (cost, capital intensity, skills and infrastructure requirement, and the accessibility of the ginning technologies), which also served as our basic social processes (BSP). Ginning technology development has always focused on obtaining optimum fibre parameters at the lowest cost (Estur and Gergely, 2010). Hence, we followed Estur and Gergely (2010) to focus on investment costs for a given ginning capacity, 
ginning outturn ratio, labour, energy, maintenance requirements and quality premiums to analyse appropriateness' of the ginning technologies we studies. In our effort to ensure the relevance of our BSP, we probed the data to identify recurrent phrases which were also 'analytically converted' (Strauss, 1978, p. 30) to fit into these categories.

Third, drawing on theoretical insights from the extant literature on technology transfer and appropriateness, and relevant key indicators including; easiness to transfer the technology to Uganda, the identified segments were then analysed and interpreted iteratively until common themes emerged and became saturated (Suddaby, 2006). These themes were then sorted, reconstituted (Strauss and Corbin, 2008), and indexed to generate the analytical categories of capacity of the ginning technology, gin acquisition cost, maintenance cost, repair cost, energy cost, labour cost, and ginning out-turn which we used to explore viable explanations of the appropriateness of ginning technologies from emerging economies relative to those from advanced countries two ginning technologies.

In the following section, we present our comparative findings of the appropriateness of the two competing technologies.

\section{Research Findings}

\section{Technology transfer through trade}

The American and Indian ginning technologies are both manufactured by the transnational corporations (TNCs) in their respective countries. The Lumus Corporation in USA and the Indian Bajaj Steel industries in India are respectively responsible for the manufacture of saw and the double roller ginning machines. Just as indicated above, import of both technologies from their country of origin to their final destination in Uganda, is usually through the Mombasa seaport in Kenya and it is done by the cotton ginning firms. This is then subjected to a series of documentation processes at the Mombasa port. After successfully completing all the bureaucratic processes, the goods are then transported by road from the Mombasa port through the Malaba border crossing to Uganda. We observe that these processes are very laborious and time consuming for importers. This is largely due 
to the fact that Uganda is a landlocked country and so will have to import the technology through the Mombasa port in Kenya. For instance, an importer will have to spend an average of 154 hours at the port to get a border compliance approval-10 hours more than the average in sub-Saharan Africa. Similarly, technology importers will spend an average of 138 hours to complete a documentary compliance process relative to an average 107.4 hours for sub-Saharan Africa.

\section{Insert Table 2 about here}

According to an official at the Ugandan Revenue Authority, the cost of transporting the ginning technology into Uganda is $100 \%$ more expensive than those that are imported into Kenya and 153\% more expensive compared to those of Tanzania. This was confirmed by one of the managers of the double roller ginnery who is responsible for importing ginning machines-she explained:

I spend US\$ 1500 to import ginning machines to the Mombasa port......though there are several regional treaties; I always pay additional $\$ 1,500$ at the Mombasa port as port charges.If it comes through the Dares Salaam port, I need about US\$2300 to import the machines [ginning machine]. Can you believe I pay an extra US\$ 3800 for port charges and warehousing? Transport cost from the port to Kampala can also cost more than US\$3000.00.

However, because of the bulky nature of the Lumus ginning machine, its cost of transportation is almost $75 \%$ as high as that of the Indian Bajaj ginning machine. The owner of the Lumus saw ginnery provided insight into the cost involved in the importation of a Lumus saw gin:

Importing this machine [Lumus saw gin] was very simple for me but it was very expensive. The manufacturers were responsible for the transport of the machine to Uganda but I am the one who incurred all the cost. I paid \$US 2500 for the importation. They charge a higher rate because it occupies a lot of space on the ship but that is not the issue, the issue is how to transport it by road from Mombassa to Uganda. That alone cost me US\$ 3000.

Clearly, the fact that a technology is appropriate does not mean it can always be affordable, transferred and accessed in the recipient country. The location of the country and ability to easily import the technology can also determine the cost of the technology. This implies that the "landlockedness" can limit the extent to which appropriate technology is transferred into the country. 


\section{Financing of technology transfer}

Though importers of the two alternative technologies face challenges in the importation of the technologies, the appropriateness of the technology is a major impetus for financing the technology transfer into Uganda. For instance, the perceived appropriate nature of the double roller ginning technology is serving as an incentive for authorities in Uganda to financially support their transfer into Uganda. Specifically, the Uganda Ginners and Cotton Exporters Association Limited (UGCEA) and the Cotton Development Organisation (CDO) often facilitate the processes of securing loans and some financial support from the government to support the importation of the Indian double roller gins. This is because compared to those from the saw gins, the double roller gins is cheaper to maintain, and produce high quality cotton lint, which attract high premium price on the international market. We will discuss the appropriateness of these alternative technologies in more details in a later section of this paper.

Officials of the double roller ginnery firm confirmed that they have successfully secured loans from financial institutions with CDO and UGCEA serving as guarantors. They also get reference letters from these two organisations to their suppliers, often the Bajaj Company in India, for a 3 months trade credit. The production manager of CDO lamented:

It is very difficult to get apply for loans as a ginnery and get it from these people [financial institutions], so we go through either CDO or UGCEA to secure some funding [Loans] from the Banks. UGCEA guaranteed our loan application for us in 2006 and 2009 but last year [2011], we were able to get CDO to guarantee it for us. Sometimes we take reference letters from our CDO and UGCEA to our suppliers for a 3 month trade credit.

Those who import from the USA face are often not able to get support from the CDOs and UGCEA. This is because the CDO and UGCEA continue to discourage the importation of cotton saw gins, with the view that the quality of cotton produced by the saw gins does not attract premium prices, despite the fact that the saw gins are often known to produce clean quality cotton lint. Interviews with the production manager at the saw ginnery show that they don't rely on support from the CDO and UGCEA mainly because as investors, they have the capital to invest. The production manager further 
added that their preference for the saw gins is largely because they have ready market for their cotton, irrespective of the fact that they do not attract premium price for their product.

\section{Cross border movement of personnel}

Cross border movement of personnel is very crucial in the transfer of ginning technologies into Uganda (see Maskus, 2004; and Bozeman, 2000). Our field observation shows that ginning technology imports from the emerging economies into Uganda are often accompanied by experts who undertake installation works at the final destination of the technology. On the average the double roller ginnery spends $\$ 3000$ for the upkeep of these expatriate workers in Uganda. These experts facilitate the transfer of soft technology, in the form of knowledge and skills transfer, to the society. They train machine operators of the double roller gins on how to use the technology. At the end of the training programme, the Indian expatriates go back to their mother company in India.

After acquiring training from the Indian experts, the cotton ginners are able to host ginning technology students from Busitema University for internship programmes as well as train local employees on how to use the technology. In addition to the knowledge acquired in the classroom, such internships ends up equipping students with the practical aspect of cotton ginning in Uganda and also develop their employable skills in cotton ginning. According to the lecturers at the ginning training school at Busitema University, the University is the only type in Eastern and Central Africa. In addition, the Indian government occasionally facilitates some refresher courses for the lecturers in the University so as to be informed about new ginning technological innovations in India. Thus though the cost of importing a ginning technology may be high, there is an efficient transfer of technological know-how from the Indians to the cotton ginners and ginning technology students and Lecturers at Busitema University. One Busitema student observed that:

This form of training is very good for me because it has helped me acquire knowledge which could have cost me thousands of dollars to acquire. 
This makes access to ginning technology information and knowledge cheaper and easier for local Ugandans - an important indicator for appropriateness of technology (Stewart 1982, and Kaplinsky 1990).

Our field observations further show that working conditions in the Lumus ginnery-as a result of the nature of the technologies in the ginnery-makes it less appropriate of the poor compared to those from the emerging economies. Expatriate workers in the Lumus ginnery are all from USA, and the cost of their upkeep is three times $(\mathrm{US} \$ 9,000)$ more than that of Indian experts. We further observed that engineers from the USA prefer to maintain the standard of living they are used to in the USA in Uganda and this makes it more expensive for the management at the Lumus ginnery compared to those in the double roller ginnery. The challenge is compounded by the fact that the Lumus gins are bulky, sophisticated and require highly skilled engineers who are original manufacturers of the technology to install them. As such, management of the Lumus ginnery has no option than to opt for these skilled engineers from USA anytime the technology breaks down. Unfortunately, these expatriates often do not train local Ugandans. Interviews with some senior staff at the ginnery shows that the American expatriates will demand higher rates if they are made to train local Ugandans on how to operate, maintain and repair the Lumus ginning machine. Local Ugandans who work at the ginnery are only given the opportunity to feed the ginneries with cotton as well as cleaning of the ginneries. They also undertake various packaging and processing activities including taking data on the quantity of cotton lint produced per given period of time.

\section{Capacity of the ginning technology}

As indicated above, the processing capacity of the saw gin stands is bigger than roller gins. The number of saws, their speed and diameter are the key capacity determinants for the saw ginning technology. As shown in Table 4, the saw gin in Uganda has 170 saws with a speed of 3.4 tonnes lint/hour. This figure was arrived at by practically measuring the rate at which each saw in the 
ginnery gins cotton lint. This measurement was undertaken by the local Ugandans with assistance from the ginnery engineers.

Interviews with the ginning engineers show that the capacity of the roller gin is determined by the number of rollers-whether it is a double roller gin. With assistance from the ginnery engineers, we measured the quantity of cotton lint (in tonnes per hour) that is produced per a gin stand. In total, a double roller gin produces 0.055 tonnes of lint/hour (Table 4). This means that cotton ginners who use the double roller gins will require a total of 62 roller gin stands to be able to produce the quantity of cotton lint that can be ginned by a 170 saw gin per given period of time. A confirmation of the fact that technologies from the northern economies including those from the north operate on large scale and so may not be appropriate for developing countries like Uganda.

\section{Insert Table 3 about here}

\section{Gin acquisition cost}

The cost of a ginnery varies according to the capacity of the equipment and the country of origin. The lower the capacity of the gin, the cheaper it becomes (Lumus, 2013). Generally, the double roller ginning technologies from the emerging economies are less expensive compared to those from the USA. The acquisition cost of a US 170 saw gin is US\$ 300,000 and that of the double roller gin from USA is US\$ 3,000 (Table 4). As explained above, one will require a total of 62 roller gins to be able to gin the quantity of cotton lint that a 170 saw gin will be able to gin per given period of time. This implies that the total acquisition cost of 62 double roller ginning technologies is US\$186,000, 38\% less than that of the investment cost of the 170 saw gin.

Following Kaplinsky (1990) this paper computes the annual capital cost of the ginning technology charged by taking a ratio between discounted acquisition cost and the average discount rate within the assumed life span of the ginning machine. Based on the prevailing real market rates at the time of the data collection, the study employs a discount rate of $9.8 \%$. The study assumes a 10 
year life span and each of the technologies were acquired brand new. The annual capital cost charged for the double roller ginning machine from the emerging economies is US\$ 504. Thus, the total cost of the 62 double roller ginning technologies is US\$ 31,248 and that of the 170 saw gin is US\$ 50,400 (see Table 2 below).

Similar to our observation above, the double roller ginning technologies appear to be more appropriate for Uganda when compared to the 170 saw gin. But this may not be a sufficient condition, considering that not many people may be able to acquire the technology in Uganda. Income earnings for more than $70 \%$ of households in Uganda fall within the $5^{\text {th }}$ quintile (Table 5). In addition, only $16.9 \%$ and $5.3 \%$ of households in urban and rural communities respectively earn more than a million Ugandan Shillings per year (Table 6). This means that more than $80 \%$ of Ugandans may not be able to acquire the double roller gins even if we consider Schumacher's proposal of the production of $\$ 100$ intermediate technology. Thus, acquisition costs of both technologies are not appropriate for developing countries. This violates the appropriate technology concept which stipulates that technology must be affordable.

\section{Skills required for the operation of the machine}

\section{Saw Ginnery}

The saw gin is highly automated and skills intensive and it is the casual workers in the firm who are directly responsible for operating the machine. All the casual workers in the saw ginnery often undergo training on how to operate the Lumus saw gin and its auxiliary parts before given the opportunity to operate the machine. One of the machine operators explained that:

This machine is big and very complicated....you cannot operate it without any training. I had my training on how to use this machine 10 years ago.

An experienced casual worker, pointing to the machine observes that:

This machine is very strong and good but very difficult to operate. It is highly computerized. You need a lot of training before you can operate it. You must be computer literate before you can work well with it. 
Fortunately, the casual workers benefit from the expertise of the permanent workers who are well trained ginning technology engineers. One important observation we made is that the American expatriates who visit the firm often do not provide any training for the permanent workers, and so these engineers often rely on their own experience and skills that they have acquired over the years. Thus, the firms are able to secure an upgrade of the hard component of the technology but the soft component, which is the knowledge and skills, is seldom upgraded through the expatriate workers. One of the engineers in the ginnery explained that

These expatriate workers take a lot of money but they don't give us any training. They just fix the machines and then make sure they are working. Maybe they are hiding something from us.

On average, the saw ginnery employs 121 saw gin plant operators and 30 permanent staff. This includes casual workers and permanent workers. Permanent workers at the saw ginnery earn higher wages and are mainly workers who are highly skilled and also perform supervisory roles e.g. engineers. The casual workers are hired on temporal basis because cotton ginning is a seasonal job. On average, the firm pays an average wage rate of US\$ 19.5 a month.

\section{Double roller ginnery}

Unlike the 170 saw gin that employs 121 ginnery operators, the double roller firm employs 240 gin operators for the double roller ginnery (i.e. one machine operator to one double roller gin). Just as the saw ginnery, the gin operators are responsible for a ginnery. This is due to the more number of gin stands and the less automated operation system of the gin stands. Thus, each double roller gin stand operator requires minimum or no skills to be able to operate the machine. Therefore compared to the saw ginnery the soft technology, which is the knowledge and skills, associated to the hard technology in the double roller ginnery appears to be more appropriate.

Compared to the saw ginnery (US\$ 19.5 per month), wages in the double roller ginnery is higher (US\$ 21 per month). The issue however with the double roller gins is that the labour involvement in the ginning process makes the feeding rate irregular and also increases contamination 
and if care is not taken, can compromise the quality of the cotton lint. So a lot of care is required during ginning so as to get clean cotton lint with the required staple length after ginning. This makes ginning laborious; and therefore, workers demand higher wages for the meticulous ginning process they undertake.

Furthermore, its production rate is slower compared to those of the Lumus saw gins. The double roller gin from emerging economies requires almost 3 man hours, whereas an American Lumus Saw Gin uses 0.33 man-hours to produce a $185 \mathrm{~kg}$ bale of cotton (Table 2.0). On average, a ginnery with double roller gin firm employs 240 workers per an 8 hour shift as compared to 121 workers for the American Lumus Saw Gin. Thus relative to the saw gins, the double roller ginning technologies are more appropriate when it comes to labour intensity of the two alternative machines.

\section{Maintenance Cost}

Maintenance of the Lumus saw gins

Regular replace of saws, frequent oiling of the machine and cleaning are the main activities that are undertaken during maintenance work. Engineers at the saw ginnery indicated to us that the average cost of a saw is $\$ 100$, and each saw must be replaced every 2 years. Each saw gin has 170 saws and each saw costs US\% 50.00. This means that a Lumus ginnery requires US\$ 8,500.00 to replace 170 gin saw blades (i.e. if the cost of each saw is US\$ 50.00). In addition, they will require an average of 20 litres of the grease for annual maintenance work. Each litre of the grease costs US\$ 2.00 on the Ugandan market, amounting to US\$ 40.00 for the 20 litres of grease. This means that the Lumus ginnery requires a total of US\$ $8,540.00$ per Lumus gin saw. This makes it very expensive for operators of the saw ginnery to maintain their ginnery, and in terms of maintenance, inappropriate for developing countries like Uganda.

\section{Maintenance of double roller gins}

Compared to the American saw gin, the double roller gins from emerging economies are mechanically simple and easier to maintain without any specialized course or programme. Though 
the ginnery employs skilled and competent ginnery engineers, most of the machine operators are able to undertake simple maintenance activities at the ginnery without direct supervision from the engineers. My field observation in the double roller ginnery shows that all the 76 casual workers were able to undertake simple maintenance works on the ginning machines after close of ginning. The leader of the casual workers at the roller ginnery explained that:

I can dismantle this machine [double roller gins] into pieces and clean all the left over lint and re-assemble them.

Another leader of the casual workers said that:

This machine is very easy to maintain that is why I like it [double roller gin]. I find it very easy to clean and oil every part of the machine.

Maintenance of the gins is mostly undertaken through regular replacement of worn out parts of certain key parts of the gin. In the case of the double roller gin, the cotton rollers and the bearings are the most important parts to frequently replace.

According to the ginnery engineer in the double roller ginnery, originally, the roller-covering material for double rollers is usually made of leather shafts and each leather shaft costs US\$ 1000 (US\$ 500/year). Each of the leather shafts on the rollers must be changed on the average every two years ${ }^{3}$. This becomes very expensive for the ginnery. The coping strategy is to use leather from cows to produce the rollers. These locally fabricated leather rollers can be used for a year. Field interviews with the engineers at the double roller ginnery indicate that the cost of the fabricated leather roller is $\$ 5.00$ instead of $\$ 1000$ for the exotic ones. The demerit for the fabricated leather rollers is that they must be replaced every year compared to 2 years for the exotic ones. An engineer from the double roller ginnery indicated that:

We don't buy the foreign rollers. In fact using leather from our local cows to produce leather rollers is far better because it rolls better cotton [cotton lint] than the one from India. It is also very cheap and very easy to fabricate.

\footnotetext{
${ }^{3}$ It must be emphasised that the rate of changed usually depends on the variety and nature of seed cotton.
} 
The double rollers are manufactured in such a way that the bearing is changed every 3 months and it requires an average of $45 \mathrm{~g}$ of grease per hour in order to operate more efficiently. The cost of the grease and the bearings for a double roller gin stand is US\$ 4.00. In total, a double roller ginnery will require an average of US\$ 9.00 to maintain a gin (i.e. US\$ 558.00 per year for 62 double roller gins).

Thus relative to the saw gins, the double roller gins appears to be more appropriate in terms of maintenance and its associated cost. The use of fabricated leathers rollers makes the cost of maintaining the double roller gins cheaper than that of the saw gin. The less skills intensive nature of the double roller ginning technology makes the double roller gins appropriate in terms of cost of maintenance.

\section{Repair Cost}

Repairs of the saw ginning technologies depend of availability of spare parts and competent skilled repairers. Availability of spare parts for the northern made Lumus saw gin is not readily available at the Ugandan local market. Almost all the parts are ordered from the manufacturers anytime there is a breakdown. Repair works are also done by the manufacturers. Thus, ginning is always suspended anytime the machine breakdown. The complicated nature of the saw ginning machine makes it very difficult for ginners to repair them. A local engineer in the saw ginnery explains that:

We are always limited. We don't get the training on how to repair broken parts of this machine; it is a very complicated machine. Our responsibility is to keep up to date records on how each machine is functioning in this ginnery.

The owner of the ginning firm indicated that they undertake repair works on the saw gin every 6 months. He further indicates that on the average, the firm spends $\$ 3000$ to hire an expatriate repairers anytime a saw ginning machine breakdown. Thus, the complicated nature of the machine and inability of the local engineers and operators of the saw acquire the skills on how to repair the machine makes the Lumus ginning machine not appropriate for the poor.

Local engineers and in some instances, machine operators in the double roller ginnery are able to repair the machines anytime it breakdown. They have very good understanding on how the 
ginning machine operates. This is coupled with the fact that spare parts of the double roller ginning machines are readily available on the local market. Similar to the saw gins, repairs works is undertaken on the double roller ginnery every 6 months and this is done by local repairers. I must indicate that the engineers acquired the skills through cross border movement of expatriate workers at the installation stage of the machine. These expatriate provide simple training to the ginners and ensures that local repairers are able to repair the machine in their absence. The manager of the double roller ginnery indicates that he spends US\$ 310 per year on repair works.

\section{Energy Cost}

Energy is one of the major issues facing the ginning sector in Uganda. All the ginneries are located in rural areas where there is no electricity infrastructure. So, most ginners use diesel to power the ginneries. The owner of the double roller ginnery indicates that each gin stand uses 200 litres of diesel a week and the cost of one litre of diesel is US\$ 0.58. This means that the ginning machine consumes US\$ 5,568 worth of diesel a year. The saw gin on the other hand consumes 4000 litres of diesel a month. With the cost of a litre of diesel estimated at US\$ 0.58, saw ginnery spends a total of US\$ 27,840 on diesel annually. Thus, energy requirement of the two technologies is capital intensive and may be expensive for local Ugandans to invest in, particularly when we consider this from the perspective of those who live below US\$2 a day.

\section{Environmental appropriateness of the alternative technologies}

However, officials of the Uganda Standards Authority, the Indian Bajaj gins emit more greenhouse gases compared to those from the USA. The Uganda Standards Authority often conducts annual monitoring exercise on the various machines that are imported into the country. They indicated that the Bajaj ginning machines emits more than twice the amount of GHG that are emitted by a Lumus cotton gin and this has been consistent between 2007 and 2012. They explained this with data from 2007 to 2012. The data shows that avaerage GHG emissions from the Lumus cotton gins over the 
period indicated above is $0.093651 \mathrm{CO} 2 \mathrm{eq} / \mathrm{kg}$ Cotton yarn. The roller gins on the hand emit 0.161025 $\mathrm{CO} 2 \mathrm{eq} / \mathrm{kg}$ Cotton yarn for the same period.

They also measure the amount of sound pollution caused by each of the two alternative technologies. Each double roller and saw cotton ginnery produces an average of 120 decibels and 90 decibels of sound per production day respectively. This means that relative to the saw gins, the double roller gins are inappropriate in terms of sound pollution and GHG emissions. Though the double roller gins may appear to be generally appropriate in Uganda, it is not environmentally friendly. Lack of standards enforcement is mainly the reason why such technologies are imported into the country. Though the Ugandan Standards Authority is aware of these GHG emissions from the ginneries, they often overlook them with the view that Uganda encourages the importation of industrial technologies and so as a policy, they encourage importation of such technologies.

\section{Ginning Out-turn}

The ginning outturn (GOT) of a ginnery is measured by the lint percentage of the seed cotton, the weight of foreign matter as well as trash in seed cotton and the moisture content before and after ginning (Estur and Gurgely, 2010). The proportions of lint in clean seed cotton and are determined by the weight of lint per seed. The roller gin is a slower and softer process than saw ginning, and it gets rid of less foreign matter, hence leading to better ginning outurn for the ginner (Estur and Gurgely, 2010). However, it means that it will produce more trash for the end-users (Estur and Gurgely, 2010). Data from the two ginning firms show that GOT for the double roller gin is $34 \%$ and that of the saw gin is $31 \%$. The roller gins produce longer staple length, less short fiber, and fragmented seed coat than the same cottons ginned with saws. As such, roller ginned cotton commands a price premium. However, if care is not taken, the level of contamination of the cotton lint can offset the premium. However, the Indian Double roller gin produces a longer staple length (1/8 inches) which is of high demand on the international market compared to that of the short staple length produced by the American Lumus saw gin (1/16 inches). This means that the double roller technology from emerging 
economies may have their own challenges but stands a better chance of producing long staple high quality premium priced staples, hence, more appropriate in terms of quality of output.

\section{Discussion and conclusion}

The crisis in the growth model in the Northern economies has presented a very good space for the boom in some emerging economies like China and India, to facilitate development in Africa (Broadman, 2008; Shaw, et al., 2007). Such change might provide manifold opportunities for those at the bottom of the pyramid to have access to appropriate technologies required to improve upon their livelihoods (Tull, 2006; Kaplinsky and Morris, 2010). It is in this regard that we examined the appropriateness of hard and soft ginning technologies transferred from the USA and India on the basis of their capacity, acquisition cost, maintenance cost, repair cost and ginning out-turn in the case of hard technology, and skills and knowledge in the case of soft technology. Our study shows that both the hard and soft components of a technology must be appropriate. The transfer of an appropriate hard technology without the soft component will make the former inappropriate; unless the country/or firm is endowed with knowledge and skills required for efficient operation of the hard technology. We also argue that soft technologies-knowledge and skills-transferred into a country must be further transferable to all users of the technology. We further show that the saw ginnery bring in expatriates from USA for installation and repairs, but do not train the machine operators how to operate the machine efficiently. This impedes smooth transfer of technology into the saw ginnery.

While we accept that soft and hard technologies from emerging economies may be appropriate, we argue that an appropriate technology in addition to its problem solving abilities can best achieve its purpose if the poorest of the poor can also afford them. We realise that the double roller ginning machine is still very expensive for the poorest of the poor despite the fact that it is less knowledge and skills intensive, easier to repair with lower maintenance cost and operate on smaller scale compared to those from the northern economies. This is aggravated by the fact that the country is landlocked and so incurs very high cost in transiting the technologies from the Mombasa port to 
Uganda. We also argue that it will be very difficult for a technology to meet all socioeconomic and environmental conditions required for it to be "fully" appropriate for an economy. For instance, though the double roller gins appear to be pro-poor, they are not environmentally appropriate. This is mainly because as a policy Uganda does not enforce standards on these technologies. As a result of the country's lack of technological capability; it finds it important to relax standards to encourage the importation of industrial technologies. The findings from our study demonstrates that the rise of the India and China in technological development provides a good opportunity for developing countries like Uganda to have open access to appropriate technologies they require for industrialisation and ultimately create jobs for poverty reduction. But this will be realised if cautious efforts are made to identify technologies that people who earn $\$ 2$ a day can acquire.

As a policy, Uganda can take advantage of this cheap source of labour to build capacity in the area of technology utilisation and development. This will create opportunities for Ugandan indigenous businessmen to get the appropriate labour required for their businesses. It will also help entrepreneurs to identify the most appropriate type of technologies required in Uganda. Productivity is likely to rise since issues regarding machine inefficiencies will decline significant (see Stewart, 1982). There is also the need for Uganda to provide financial support for STI activities to keep skilled labour in the industry and also support them to be able to transfer the skills they have acquired to others. This can be done by putting in place practical oriented educational and training systems that produces human resources that can apply contemporary technologies to increase productivity. On another note, one reason why the double roller cotton gin appears to be capital intensive for the poorest of the poor is because of the build-up cost at the port in Kenya and Tanzania. We encourage the Ugandan government to support technological import by negotiating with the Kenya and Tanzania through the East African Community to waive such port charges. In addition, the double roller ginning technology is small in nature, simple and less capital intensive compared to those from the north. Though the cost remains high for those at the bottom of the pyramid, the simplicity of the 
machine means that government in the long-term can build the capacity of local Ugandans in this area to manufacture these technologies for both local and international consumption.

For future research, we encourage future technology and innovation scholars to focus on (re)examining the appropriateness of industrial technologies from the West and East making their way into developing countries, particularly in Africa. This will provide a holistic view of the appropriateness of Asian Driver technologies, and their potential influence on economic development in the third world. It is possible that the Indian technologies in other sector are not appropriate. We must emphasise that evidence in Kenya shows that technologies in the Jua Kali sector are appropriate (see Atta-Ankomah, 2014). However, this is still not enough since there is different spectrum of technologies spread across different sectors (and sub-sectors) in developing countries including Uganda. One of the key barriers of industrialisation in developing countries is lack of technologies. In an era where Africa has become the new economic frontier for India and China, there is the need to ascertain whether technologies from the Asian Driver economies will enable African countries to boost their productivity and drive the needed economic growth they desire.

\section{References}

Ahmed, M. and Ojangole, S. (2012) Analysis of incentives and disincentives for cotton in Uganda, Technical notes series, MAFAP, FAO, Rome.

Aitken, B. J., and Harrison, A. E. (1999). Do domestic firms benefit from direct foreign investment? Evidence from Venezuela. American Economic Review, 89, 3, 605-618.

Amankwah-Amoah, J. (2015). Solar energy in sub-Saharan Africa: The challenges and opportunities of technological leapfrogging. Thunderbird International Business Review, 57, 1, 15-31.

Amanor, K. S., \& Chichava, S. (2016). South-south cooperation, agribusiness, and African agricultural development: Brazil and China in Ghana and Mozambique. World Development, 81, 13-23.

Amin Almfrajia and Almsafirc (2014) Economic Growth and Foreign Direct Investment Inflows: The Case of Qatar, 2ndWorld Conference On Business, Economics And ManagementWCBEM2013, Procedia-Social and Behavioral Sciences 109, 1040 -1045. 
Anthony, W.S. and Mayfield, W.D. (1994). Cotton ginners' handbook (No. 503). Collingdale, PA: Diane Publishing.

Archibugi, D and Pietrobelli, C. (2003). The globalisation of technology and its implications for developing countries: Windows of opportunity or further burden? Technological Forecasting and Social Change, 70, 9, 861-883.

Atta-Ankomah, Richmond (2014). China's Presence in Developing Countries' Technology Basket: The Case of Furniture Manufacturing in Kenya. PhD thesis The Open University, UK.

Baffes, J. (2009). The Cotton Sector of Uganda, Africa Region Working Paper Series, World Bank, No. 123, pp.8.

Bascavusoglu, E. (2005). Does International Trade Transfer Technology to Emerging countries? A

Patent Citation Analysis, An Open University research centre on Innovation, Knowledge and Development, Working Paper No 14. pp. 4-6.

Bell, M. and Pavitt, K. (1993). Technological accumulation and industrial growth: Contrast between developed and developing countries, Industrial and Corporate Change, 2, 2, 157-211.

Bhalla, A.S. (1985). Technology and Employment in industry, International Labour Organization, $2^{\text {nd }}$, revised and enlarged edition, pp. 25-42.

Bi, J., Sarpong, D., Botchie, D. and Rao-Nicholson (2017) From imitation to innovation: The discursive processes of knowledge creation in the Chinese space industry, Technological Forecasting and Social Change, http://dx.doi.org/10.1016/j.techfore.2017.01.008.

Borensztein, E. De Gregorio, J. and Lee, J-W. (1998). How does foreign direct investment affect economic growth? Journal of International Economics 45, 1, 115-135.

Botchie, D. (2015). Distinctiveness of Asian Driver and Western garment technologies in Uganda. An unpublished PhD dissertation, The Open University, UK.

Botchie, D., Sarpong, D. and Bi, J. (2016) Technological inclusiveness: Northern versus Chinese induced technologies in the garment industry, Technological Forecasting and Social Change. doi.org/10.1016/j.techfore.2016.04.011

Bozeman, B. (2000). Technology transfer and public policy: a review of research and theory, Research Policy, 29, 4-5, 627-655.

Broadman, H.G. (2008). China and India go to Africa: New deals in the developing world. Foreign Affairs, 87, 2, 95-109.

Burgess, T. F. and Gules, H. K. (1998). "Buyer-supplier relationships in firms adopting advanced manufacturing technology: an empirical analysis of the implementation of hard and soft technologies". Journal of Engineering and Technology Management,15, pages 127-152.

Chataway, J., Hanlin, R. and Kaplinsky, R. (2014). Inclusive innovation: An architecture for policy development, Innovation and Development, 4, 1, 33-54. 
Chun, C. L. (2006). Modeling the Technology Transfer to Taiwan from China. Journal of International BusinessResearch, 5, 23 -35.

Clark, P.A. and Staunton, N. (1989). Innovation in Technology and Organisation, Routledge: London.

Coe, D. T., Helpman, E. and Hoffmaister, A. (1997). North-South research and development spillovers, $\quad$ The Economic Journal, 107, 134-149.

Collier, P. (1999). On the Economic Consequences of Civil War, Oxford Economic Paper, 51, 1, 168-183.

Costantini, V and Liberati, P. (2014). Technology transfer, institutions and development, Technological Forecasting and Social Change, 88, 26-48.

Cotton Development Organisation (CDO) (2009). The Ugandan Cotton Sector report for 2008 Republic of Uganda.

da Nobrega Cesarino, L. M. C. (2013). South-South cooperation across the Atlantic: emerging interfaces in international development and technology transfer in agriculture. University of California, Berkeley.

David, P. A., and Foray, D. (2001). "An Introduction to the Economy of the Knowledge Society", Department of Economics, University of Oxford discussion paper series, 84, 1-10.

Dey, B. L., Binsardi, A., Prendergast, R. and Saren, M. (2013), "A qualitative enquiry into the appropriation of mobile telephony at the Bottom of the Pyramid", International Marketing Review, Vol. 30. No. 4, pp. 297-322.

Dobler, D. W., Burt, D. N. and Lee Jr., L.L. (1990). Purchasing and Materials Management: Text and Cases 5th Edition. NY, New York: McGraw-Hill, Inc., 842.

Estur, G. and Gergely, N. (2010). The Economics of roller ginning technology and implications for for African Cotton Sector Africa Region Working Paper Series No. 129 (a).

Faye, M. L., McCarthur J. W., Sachs, J D. and Snow, T. (2004). The Challenges facing landlocked developing countries, Journal of Human Development 5, 1, 2-26.

Findlay, R. (1978). Relative backwardness, direct foreign investment, and the transfer of technology: a simple dynamic model, Quarterly Journal of Economics, 92, 1-16.

Fu, X. and Gong, Y. (2011) Indigenous and Foreign Innovation Efforts and Drivers of Technological Upgrading: Evidence from China,, World Development, 39, 1213-1225.

Fu, X. Pietrobelli, C. \& Soete, L. (2011). The role of foreign technology and indigenous innovation in the emerging economies: Technological change and catching-up. World Development, 39(7), 12041212.

Glaser, B.G., and Strauss, A.L. (2012) The Discovery of Grounded Theory: Strategies for York Qualitative Research, Aldine Publications Company. 
GoU (2008). “Uganda Industrial Policy- A Framework for Uganda's Transformation, Competitiveness and Prosperity" published by the Uganda Ministry of Tourism, Trade and Industry, pages 1134.

GoU (2009). "Uganda National Textiles Policy", a document published by the Uganda Ministry of Tourism, Trade, and Industry, pages 4-23.

GoU (2010). “Uganda National Development Plan 2010/11-2014/15”, pages. 7-25 this paper is available on the IMF website as a Poverty Reduction Strategy Paper, also available on http://www.imf.org.

GoU (2012). "Government of Uganda Statistical Abstract, 2012", report published by the Uganda Bureau of statistics, pages 23-29.

GoU (2013). "Uganda Statistical Abstratct-2013”, a report produced by Uganda Bureau of Statistics, pages 20-41.

Gordon, S. and Hsieh, Y.L. (2006) Cotton: Science and technology. Cambridge: Woodhead Publishing.

Hassan, A., Jamaluddin, M.Y. and Menshawi, K.M. (2015). International technology transfer models: A comparison study. Journal of Theoretical and Applied Information Technology, 78, 1, 95-98.

Hazeltine, B., \& Bull, C. (Eds.). (2003). Field guide to appropriate technology. Academic Press.

Hewitt-Taylor J (2001) Use of constant comparative analysis in qualitative research. Nursing Standard. $\quad 15,42,39-42$.

Iamsiraroj S. and Ulubaşoğlu M.A. (2015) Foreign direct investment and economic growth: A real relationship or wishful thinking?, Economic Modelling 51 Pg 200-213.

Jensen, M.B., Johnson, B., Lorenz, E. and Lundvall, B.-Å. (2007). 'Forms of knowledge and modes of innovation', Research Policy, 36, 680-693.

Jin, Z. (2005). Global technological change from hard technology to soft technology, first edition, Intellect limited.

Johnson, B, and Lundvall, B-Å. (2001). "Why all this fuss about codified and tacit knowledge?" paper presented at the DRUID Winter Conference, Korsør, Denmark, January 18-20.

Kapliinsky, R. (2011a). Schumacher meets Schumpeter: Appropriate technology below the radar, Research Policy, 40, 2, 193-203.

Kaplinsky, R. (2011b). Bottom of the pyramid innovation and Pro-Poor Growth", IKD Working Paper No. 62, Open University, UK.

Kaplinsky, R. (1990). The Economies of Small: Appropriate Technology in a Changing World. Michigan, IT Publications.

Kaplinsky, R. and Morris, M. (2010). Chinese FDI in Sub-Saharan Africa: Engaging with large dragons. European Journal of Development Research, 21, 4, 551-569. 
Lamming, R. C. (1993). Beyond partnership - Strategies for innovation and lean supply, Prentice Hall, Hemel Hemstead.

Lee J-Y. and Mansfield, E. (1996). Intellectual property protection and U.S foreign direct investment, Review of Economic and Statistics, 78, 2, 181-186.

Lema, R., \& Lema, A. (2012). Technology transfer? The rise of China and India in green technology sectors. Innovation and Development, 2(1), 23-44.

Li-Hua, R. (2006). Examining the appropriateness and effectiveness of technology transfer in China. Journal of Technology Management in China, 1, 2, 208-223.

Los, B., \& Timmer, M. P. (2005). The 'appropriate technology' explanation of productivity growth differentials: an empirical approach. Journal of Development Economics, 77(2), 517-531.

Lumus (2013) Imperial III ${ }^{\mathrm{TM}}$ Saw Gins, http://www.lummus.com/tech_saw_gins.pdf.

Majidpour, M. (2016). International technology transfer and the dynamics of complementarity: A new approach, Technological Forecasting and Social Change dx.doi.org/10.1016/j.techfore.2016.03.004.

Mansfield, E. and Romeo, A. (1980). Technology transfer to overseas subsidiaries by U.S.- D.C.: volunteers in technical assistance, Quarterly Journal of Economics 95,4, 737-750.

Markusen, J. R. (1995). The boundaries of multinational enterprises and the theory of international trade, Journal of Economic Perspectives 9, 2, 169-190.

Maskus K.E. (2004). Encouraging international technology transfer: An UNCTAD ICTSD projection international property rights and sustainable development, Issue Paper No.7, pages 9-27.

Milner, C., Morrissey, O. and Rudaheranwa, N. (2013). Protection, Trade Policy and Transport Costs: Effective Taxation of Ugandan Exporters, Centre for Research in Economic Development and International Trade, University of Nottingham, DFID-TERP: Credit Discussion paper 7 (CDP007), pages 2-14.

Mokyr, J. (2003). Thinking about Technology and Institutions, Macalester International: Vol. 13, Article 8. Available at: http://digitalcommons.macalester.edu/macintl/vol13/iss1/8.

Morrissey O. and Rudaheranwa N. (2012). Uganda trade policy and export performance in the 1990s, Centre for Research in Economic Development and International Trade, University of Nottingham, DFID-TERP: Credit Discussion Paper No. 98/12, pages 6-28.

Mutambi, J., Byaruhanga, J.B. and Trojer, L. (2013). Promoting Innovation and Entrepreneurship in Rural Communities: Case of OVOP Program in Uganda, (Part of the paper that is in the proceedings of the 7th International OVOP Seminar 13th-14th December 2010, Hanoi, Vietnam and submitted to the AJSTID for publication), pages 5-19.

Nelson and Winter (1982), An evolutionary theory of economic change, Harvard University Press: Massachusetts.

Nicholson, M. (2002). Intellectual Property Rights and International Technology Transfer: The Impact of Industry Characteristics, U.S. Federal Trade Commission, manuscript, 2-17. 
OECD (1976). Appropriate technology: Problems and promises, Paris, OECD.

Papaioannou, T. (2014). How inclusive can innovation and development be in the twenty-first century? Innovation and Development, 4, 2, 187-202.

Patil, P. G., and P. M. Padole (2003). Double Roller cotton ginning machine, its drawback and possible modification. Proceedings of 11th National Conference on Machines and Mechanisms (NaCOMM-2003), IIT, Delhi, Dec. 2003.

Paunov, C. (2013). Innovation and Inclusive Development: A Discussion of the Main Policy Issues, OECD Science, Technology and Industry Working Papers, 2013/01, OECD, Publishing, http://dx.doi.org/10.1787/5k4dd1rvsnjj-en.

Pitula K. and Radhakrishnan T. (2007) A Conceptual Model of Inclusive Technology for Information Access by the Rural Sector. In: Stephanidis C. (eds) Universal Access in Human Computer Interaction. Coping with Diversity. UAHCI 2007. Lecture Notes in Computer Science, $\quad$ vol 4554. Springer, Berlin, Heidelberg

Polanyi, M. (1966), The Tacit Dimension, Doubleday, Garden City, New York.

Prahalad, C. K. and Hammond, A. (2002). Serving the world's poor profitably, Harvard Business Review, 89, 9, 4-11.

Ragin, C.C. (2014). The Comparative Method: Moving Beyond Qualitative and Quantitative Strategies.

California: University of California Press.

Ramanathan, K. (1994) "The polytrophic components of manufacturing technology," Technological Forecasting and Social Change, 46, 3, 221-258.

Rudaheranwa, N. (2009). Trade policy and transport costs in Uganda, CREDIT Research Paper, No. $06 / 09, \quad 6-18$

Sahal, D., (1981). "Alternative conceptions of technology", Research policy,10, 2-24.

Sahal, D., (1982). "The form of technology". in Sahal, D. (Ed)., The Transfer and Utilization of Technical Knowledge ${ }_{\iota}$ Lexington Publishing, Lexington, MA, 125-139.

Schumacher, F. (1973). Small is Beautiful, Blond and Briggs, London Sciences, Chicago: Rand McNally.

Shaw, T.M., Cooper, A.F. and Antkiewicz, A., (2007). Global and/or regional development at the start of the 21st century? China, India and (South) Africa, Third World Quarterly, 28, 7, 1255-1270.

Shoffner, M.B., Jones, M. and Harmon, S. W. (2000). Paradigms Restrained: Implications of New and Emerging Technologies for Learning and Cognition, Volume 6, Issue 1: New Information Technology and Liberal Education, http://dx.doi.org/10.3998/3336451.0006.111.

Smith, P. J. (2001) "How Do Foreign Patent Rights Affect U.S. Exports, Affiliate Sales, and Licenses?" Journal of International Economics, 55, 411-439. 
Souder, W. E., Nashar, A. S. and Padmanabhan, V. (1990) "A guide to the best technology-transfer practices," The Journal of Technology Transfer, 15, 5-16, 1990.

Stewart, F. (1982). Technology and Underdevelopment, London, Macmillan, 2nd edition, pages 1-30.

Stewart, F. and Ranis, G., (1990_. Macro-Policies for Appropriate Technology: A Synthesis of Findings. In: The Other Policy: The Influence of Policies on Technology Choice and Small Enterprise Development, eds. Stewart, F., Thomas, H. and de Wilde, T., London: Intermediate Technology Publications.

Strauss, A.L. (1978), Qualitative Analysis for Social Scientist, Cambridge University Press, Cambridge.

Suddaby, R. (2006). From the editors: what grounded theory is not, Academy of Management Journal, 49, $4,633-642$.

Tull, D.M. (2006). China's engagement in Africa: Scope, significance and consequences, Journal of Modern African Studies, 44, 3, 459-479.

UNCTAD (1999) World Investment Report 1999: Foreign Direct Investment and the Challenge of Development, United Nations, New York and Geneva.

UNCTAD, (2010). Foreign direct investment, the transfer and diffusion of technology, and sustainable development. An expert meeting on the contribution of foreign direct investment to the transfer and diffusion of technology and know-how for sustainable development in developing countries: especially least developed countries, Geneva, 16-18 February 2011, Item 3 of the provisional agenda, TD/B/C.II/EM.2/2, pages 1-18.

USAID (1976). Section 107 proposal for a programme in appropriate technology, Washington, presented at the $25^{\text {th }}$ congress of the USA, pages 1-50.

$\mathrm{Vu}, \mathrm{T} . \mathrm{B} .$, Gangnes, B. and Noy, I. (2008) Is foreign direct investment good for growth? Evidence from sectoral analysis of China and Vietnam, Journal of the Asia Pacific Economy Vol. 13, Issue. 4, 2008.

Wahab, S. A., Rose R C., and Osman, S. I. W. (2012), "Defining the Concepts of Technology and Technology Transfer: A Literature Analysis", International Business Research, 61-71.

Wang, J.Y. (1990). "Growth, technology transfer, and the long-run theory of international capital movements", Journal of International Economics, Volume 29, Issues 3-4, November 1990, pages 255-271.

Willoughby K. W. (1990), Technology choice: A critique of the appropriate technology movement, West view Press Boulder \& London, pages 7-22.

World Bank (1976). Appropriate technology in World Bank activities, Washington, page 5.

World Economic Forum (2013) The Africa Competitiveness Report, document available at: http://www.worldbank.org/content/dam/Worldbank/document/Africa/Report/africacompetitiveness-report-2013-main-report-web.pdf (accessed 20.09.2016). 
Zhang K.H. (2001) Does foreign direct investment promotes economic growth? Evidence from East Asia and Latin America, Contemporary Economic Policy, Vol. 19, No. 2, April 2001, 175-185.

Figure 1: Comparing cotton ginning imports from USA and India into Uganda (\$000)

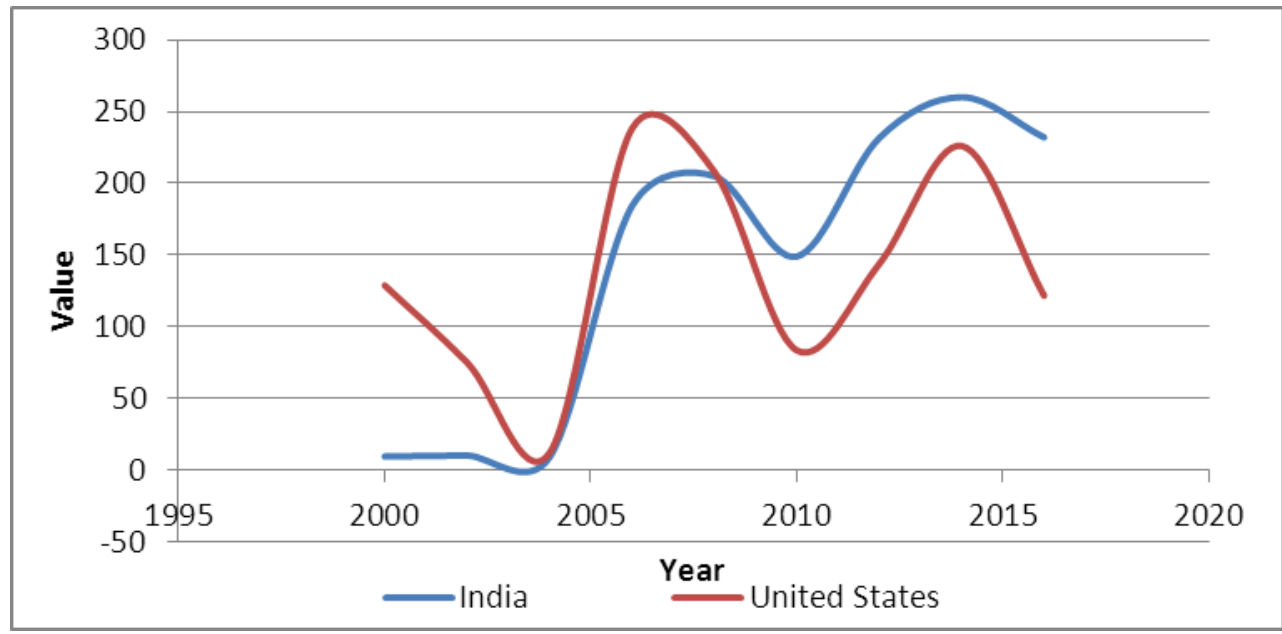

Source: WITS Database, World Bank

Table 1 Background characteristics of research participants

\begin{tabular}{|c|c|c|c|c|c|}
\hline & Double Roller Gin & $\%$ & Saw Gin & $\%$ & Total \\
\hline \multicolumn{6}{|l|}{ Age } \\
\hline $15-24$ & 3 & 4 & 5 & 12.5 & 8 \\
\hline $25-34$ & 42 & 53 & 22 & 55 & 64 \\
\hline $35-44$ & 25 & 31 & 9 & 22.5 & 34 \\
\hline 45 above & 10 & 13 & 4 & 10 & 14 \\
\hline Total & 80 & 100 & 40 & 100 & 120 \\
\hline \multicolumn{6}{|l|}{ Residence } \\
\hline Urban & 8 & 10 & 3 & 7.5 & 11 \\
\hline Rural & 72 & 90 & 37 & 92.5 & 109 \\
\hline Total & 80 & 100 & 40 & 100 & 120 \\
\hline \multicolumn{6}{|l|}{ Education } \\
\hline No Education & 4 & 5 & 7 & 17.5 & 11 \\
\hline Basic Education & 46 & 58 & 15 & 37.5 & 61 \\
\hline Secondary Education & 15 & 19 & 11 & 27.5 & 26 \\
\hline Vocational/Technical & 10 & 13 & 2 & 5 & 12 \\
\hline Tertiary & 5 & 94 & 5 & 12.5 & 10 \\
\hline Total & 80 & 100 & 40 & 100 & 120 \\
\hline $\begin{array}{l}\text { Casual staff (average } \\
\text { number per shift) }\end{array}$ & 76 & 95 & 35 & 87.5 & 111 \\
\hline
\end{tabular}




\begin{tabular}{rccccc} 
Permanent staff & 5 & 5 & 5 & 12.5 & 9 \\
\hline Total & $\mathbf{8 0}$ & $\mathbf{1 0 0}$ & $\mathbf{4 0}$ & $\mathbf{1 0 0}$ & $\mathbf{1 2 0}$
\end{tabular}

Table 2: Time involved in the transfer of ginning technologies to Uganda

\begin{tabular}{lll}
\hline & Uganda & Africa \\
\hline Border & Malaba border crossing & - \\
No. of documents required for import & 13 & - \\
Time to import: Border compliance (hours) & 154 & 144 \\
Time to import: Documentary compliance (hours) & 138 & 107.4 \\
\hline
\end{tabular}

Source: World Bank-Doing Business Report-2017

Table 3.0 Results on the properties of the alternative technologies

\begin{tabular}{|c|c|c|c|}
\hline \multirow[b]{2}{*}{ Indicators } & \multirow[b]{2}{*}{ Unit } & \multirow{2}{*}{$\begin{array}{l}\text { Double Roller Gin } \\
\text { India }\end{array}$} & \multirow{2}{*}{$\begin{array}{l}\text { Saw Gin } \\
\text { USA }\end{array}$} \\
\hline & & & \\
\hline State of equip at the time of purchase & & Brand New & Brand New \\
\hline Cost of Equipment & US\$/Gin & 3,000 & 300,000 \\
\hline Annual cost charge for ginning & & & \\
\hline machine & US\$ & 504,008 & 5,040 \\
\hline \multicolumn{4}{|l|}{ Average Ginning variable cost } \\
\hline Cost of labour & \$/year/gin stand & 5,040 & 1,936 \\
\hline Energy & $\begin{array}{l}\$ / \text { litre of diesel/ gin } \\
\text { stand }\end{array}$ & $5,568.00$ & $27,840.00$ \\
\hline Maintenance of Gins & $\$ /$ year & 9.00 & 8540 \\
\hline Repair cost & \$/year/gin stand & 310 & 3000 \\
\hline Ginning GHG emissions & $\mathrm{CO}_{2} \mathrm{eq} / \mathrm{kg}$ Cotton yarn & 0.161025 & 0.093651 \\
\hline \multicolumn{4}{|l|}{ Output/Gin stand } \\
\hline No of bales & bale/hr & 0.1 & 6.83 \\
\hline Capacity & tonnes lint/hour & $0.055^{* * *}$ & $3.40^{* * * *}$ \\
\hline
\end{tabular}




$\begin{array}{llll}\text { Ginning Outturn Test } & \% & 34 & 31 \\ \text { Staple Length } & \text { Inches } & 1 / 8 & 1 / 16\end{array}$

Computation base on field data *Monthly income paid to installers for only 3 month, ${ }^{* *}$ Monthly income for experts who are paid as regularly employees. ${ }^{* * *}$ This is capacity per gin stand, ${ }^{* * * *}$ This is the capacity for a 170 saw gin 
Table 4: Summary of appropriateness of hard and soft technologies in Uganda

\section{Double roller gin}

\begin{tabular}{|c|c|c|c|c|}
\hline Appropriateness Indicators & Hard Technology & Soft Technology & Hard Technology & Soft Technology \\
\hline \multicolumn{5}{|l|}{ 1. Mode of transfer } \\
\hline Trade & $\begin{array}{l}\text { Appropriateness is mixed: Time } \\
\text { consuming and high cost of imports } \\
\text { makes the technology which appears to } \\
\text { be appropriate less affordable. }\end{array}$ & $\begin{array}{l}\text { Appropriate: Expatriates } \\
\text { accompany the technology for } \\
\text { installation at a relatively lower fee. }\end{array}$ & $\begin{array}{l}\text { Less affordable but the time } \\
\text { consuming nature and high cost of } \\
\text { imports makes the technology more } \\
\text { inappropriate }\end{array}$ & $\begin{array}{l}\text { Inappropriate: Very expensive } \\
\text { hiring expatriates from USA for } \\
\text { installation activities. }\end{array}$ \\
\hline FDI/Cross Border & $\begin{array}{l}\text { Experts accompany the hard } \\
\text { technology to Uganda for installation } \\
\text { works. }\end{array}$ & $\begin{array}{l}\text { Indian experts train machine } \\
\text { operators for no fee. Machine } \\
\text { operators also train students after } \\
\text { acquiring the training. }\end{array}$ & $\begin{array}{l}\text { Very sophisticated and require } \\
\text { highly skilled engineers who are } \\
\text { original manufacturers of the } \\
\text { technology to install them. }\end{array}$ & $\begin{array}{l}\text { Unfortunately, experts from the } \\
\text { Lumus company in USA do not } \\
\text { train local Ugandans. }\end{array}$ \\
\hline \multicolumn{5}{|c|}{ 2. Technology specifications } \\
\hline Repair and maintenance & $\begin{array}{l}\text { Appropriate: Easy to repair and } \\
\text { maintain. Easy to fabricate parts of the } \\
\text { machine. }\end{array}$ & $\begin{array}{l}\text { Appropriate: Local operators have } \\
\text { the skills and knowledge to repair } \\
\text { and maintain them-less skills } \\
\text { intensive. }\end{array}$ & $\begin{array}{l}\text { Inappropriate: Sophisticated and } \\
\text { cannot be easily repaired and } \\
\text { maintained. }\end{array}$ & $\begin{array}{l}\text { Inappropriate: Requires } \\
\text { expatriates for repair works. } \\
\text { Maintenance cost is high. }\end{array}$ \\
\hline Acquisition cost & $\begin{array}{l}\text { Inappropriate: Low acquisition cost } \\
\text { compared to the Lumus; but less } \\
\text { affordable for the poor. }\end{array}$ & $\begin{array}{l}\text { Appropriate: Cost of experts (for } \\
\text { installation) cheaper than that of the } \\
\text { saw ginnery. }\end{array}$ & Inappropriate: Capital intensive) & $\begin{array}{l}\text { Inappropriate: Very expensive } \\
\text { to hire experts from the USA. }\end{array}$ \\
\hline Labour requirement & $\begin{array}{l}\text { Appropriate: Labour intensive and easy } \\
\text { to operate, maintain and repair the } \\
\text { technology. }\end{array}$ & $\begin{array}{l}\text { Appropriate: Less skills and } \\
\text { knowledge intensive. }\end{array}$ & Inappropriate: Less labour intensive & $\begin{array}{l}\text { Inappropriate: Skills and } \\
\text { knowledge intensive. }\end{array}$ \\
\hline Output (GOT) & $\begin{array}{l}\text { Appropriateness is mixed: Low } \\
\text { production speed but produces long } \\
\text { staple cotton lint. Command premium } \\
\text { price on the international market. }\end{array}$ & NA & $\begin{array}{l}\text { Appropriateness is mixed: produces } \\
\text { more cotton lint but with lower } \\
\text { quality. Lint prices are low on the } \\
\text { international market. }\end{array}$ & NA \\
\hline \multicolumn{5}{|c|}{ 3. Environ. appropriateness } \\
\hline Sound Pollution & $\begin{array}{l}\text { Inappropriate: High sound pollution } \\
\text { compared to the Lumus }\end{array}$ & NA & Appropriate: Acceptable sound & NA \\
\hline GHG Emissions & Inappropriate: More GHG emissions. & NA & Appropriate: Less GHG emissions. & NA \\
\hline
\end{tabular}

